\title{
PERANCANGAN WHEEL TURBINE PADA PEMBANGKIT LISTRIK MIKRO GAS TURBIN
}

\author{
Eko Prasetyo $^{1)}$, Rudi Hermawan ${ }^{1)}$, Muhammad Edza Fakhri ${ }^{2)}$, Rini Prasetyani ${ }^{3)}$ \\ Dan Erlanda Augupta Pane ${ }^{1)}$ \\ 1) Jurusan Teknik Mesin, Universitas Pancasila \\ ${ }^{2)}$ Mahasiswa Jurusan Teknik Mesin, Universitas Pancasila \\ 3) Jurusan Teknik Industri, Universitas Pancasila \\ e-mail: eko170424@gmail.com, hermawanrudi73@gmail.com, edzafakhri1257@gmail.com, \\ rini.prasetyani@univpancasila.ac.id, erlanda.pane@univpancasila.ac.id
}

\begin{abstract}
Micro gas turbine power generator has advantages in low maintenance and operational cost and can be moved easily. Gas fueled micro gas turbine generate power by delivering pressurized combustion gas to mechanical power and stored in battery via altenator. In this research, turbine whell from Garrett TA31 in micro gas turbine is redesigned to increase the system performance. Experiment of redesigned turbine wheel is then compared with the previous configuration turbine wheel performance. The results show the system power is increased from $0,23 \mathrm{~kW}$ to $3,1 \mathrm{~kW}$.
\end{abstract}

Keywords: Shaft speed, thermodynamics, micro gas turbine, turbine wheel.

\section{PENDAHULUAN}

Penelitian sistem pembangkit listrik mikro gas turbin telah dilakukan sebelumnya Energi sangat diperlukan pada saat ini untuk mendukung aktivitas dalam kehidupan sehari-hari, khususnya energi listrik semakin berkembang menjadi bagian tak terpisahkan dari seiring dengan pesatnya peningkatan pembangunan di bidang teknologi, industri dan informasi [1]. Untuk mengatasi masalah tersebut, dibutuhkanlah energi yang dihasilkan dari cara alternatif. Salah satunya adalah pembangkit listrik mikro gas turbin yang dapat di pergunakan untuk rumah tangga [1]. Pembangkit listrik mikro gas turbin memiliki keunggukan yaitu yang lebih aman dan ramah lingkungan, yang memiliki dimensi yang lebih kecil, serta biaya perawatan tidak terlalu besar [2]. Pembangkit listrik mikro gas turbin berbahan bakar gas memiliki tahapan untuk menghasilakan listrik yang berawal bahan bakar gas yang diteruskan pada ruang bakar sehingga terjadi perpidahan tekanan yang menjadi energi mekanis untuk memutarkan alternator sehingga tersimpan energi listrik pada baterai [3]. Berdasarkan latar belakang tersebut maka rumusan masalah yang akan dibahas adalah melakukan perancangan serta perhitungan ulang wheel turbine yang disesuaikan terhadap pembangkit listrik mikro gas turbin yang ada di laboratorium teknik mesin Universitas Pancasila. Batasan masalah pada penelitian ini adalah perancangan ulang hanya pada wheel turbine pembangkit listrik mikro gas turbin yang ada di laboratorium teknik mesin Universitas Pancasila, analisis software melakukan pengujian aliran fluida dan tekanan pada wheel turbine melalui Solidworks, dan bahan bakar yang digunakan untuk pengujian mikro gas turbin adalah LPG $3 \mathrm{~kg}$. Tujuan dari penelitian ini adalah perancangan ulang wheel turbine dengan penambahan turbocharger yang mengacu pada wheel turbine pembangkit listrik mikro gas turbin di laboratorium teknik mesin Universitas Pancasila, melakukan perhitungan termodinamika untuk mendapatkan wheel turbine, dan analisis pengujian aliran fluida serta tekanan wheel turbine menggunakan software Solidworks.

\section{TINJAUAN PUSTAKA}

\section{Pembangkit Listrik Tenaga Gas}

Turbin Gas adalah suatu pengerak utama yang memanfaatkan gas sebagai fluida kerja $[2,4]$. Turbin gas umum digunakan sebagai power plant dan pesawat terbang. Proses pembakaran pada turbin gas terjadi secara kontinu (terus-menerus). Di dalam sistem turbin gas energi kimia dari proses pembakaran dikonversikan menjadi energi mekanik berupa putaran yang menggerakan roda turbin sehingga menghasilkan daya [5,6]. 
Turbin gas menghasilkan proses pembakaran dengan cara mencampur udara bertekanan tinggi, hasil kompresi dari kompresor, dengan bahan bakar gas atau bahan bakar cair (solar), serta pemicu dari busi diruang bakar [2,6,7]. Gas yang bertekanan tinggi yang merupakan hasil dari proses pembakaran dan digunakan untuk memutar turbin.

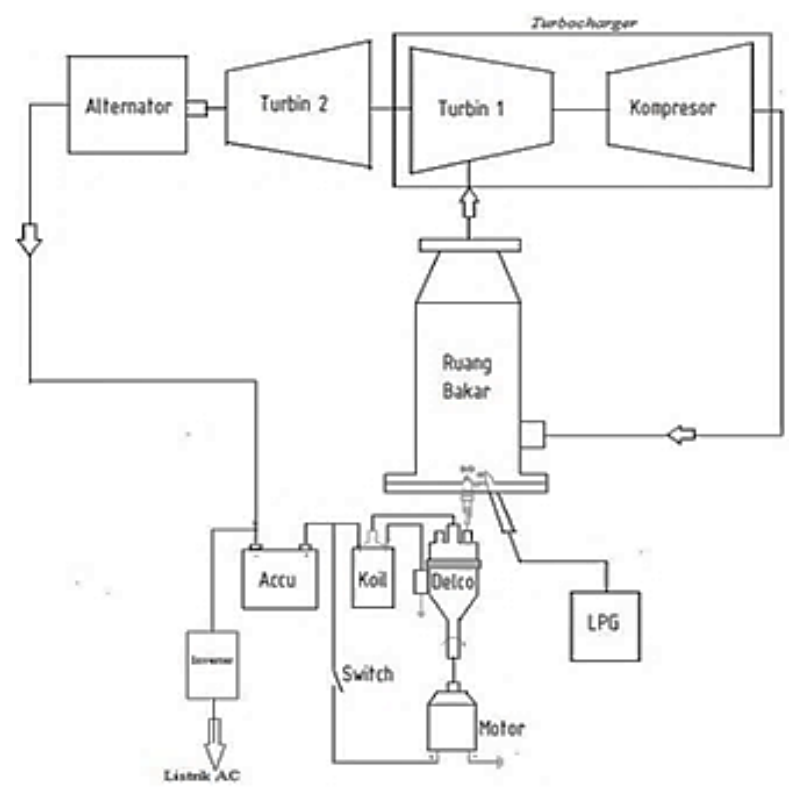

Gambar 1. Skema kerja mikro gas turbin [2]

\section{Siklus Ideal Turbin Gas Mikro}

Siklus ideal dari sistem turbin gas mikro sederhana adalah siklus Brayton. Sistem turbin gas mikro sederhana dengan siklus terbuka menggunakan ruang bakar $[1,8]$. Prinsip kerja dari turbin gas mikro adalah diawali oleh usaha meningkatkan tekanan udara sebelum dikirim ke ruang bakar oleh kompresor. Di dalam ruang bakar, udara dicampur dengan bahan bakar yang diinjeksikan. Udara bertekanan yang sudah tercampur dengan bahan bakar kemudian dibakar pada tekanan konstan sehingga menghasilkan tekanan tinggi. Udara hasil pembakaran medapatkan gaya dorong dari kompresor sehingga melewati sudu-sudu turbin. Udara bertekanan yang keluar dari turbin dipercepat oleh nosel untuk menghasilkan daya dorong. Pembakaran terjadi pada tekanan konstan. Sistem pembangkit turbin gas mikro yang sesuai dengan siklus brayton dapat dilihat pada gambar di bawah ini [1,2].
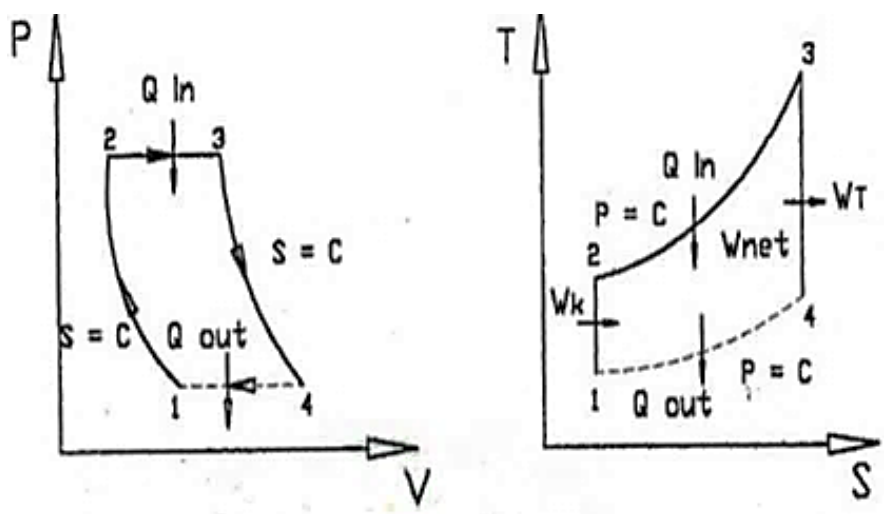

Gambar 2. Diagram P-V dan diagram T-S

Proses yang terjadi dari diagram tersebut di atas adalah kompresi isentropic di dalam kompresor (1-2), tekanan konstan saat penambahan panas di ruang bakar (2-3), ekspansi isentropic dalam turbin (3-4), dan pelepasan panas bertekanan secara konstan (4-1) [1,2]. 


\section{METODOLOGI PENELITIAN}

Dalam metodologi penelitian akan dijelaskan tahapan perancangan wheel turbine pada pembangkit listrik mikro gas turbin melalui skema diagram alir di bawah ini.

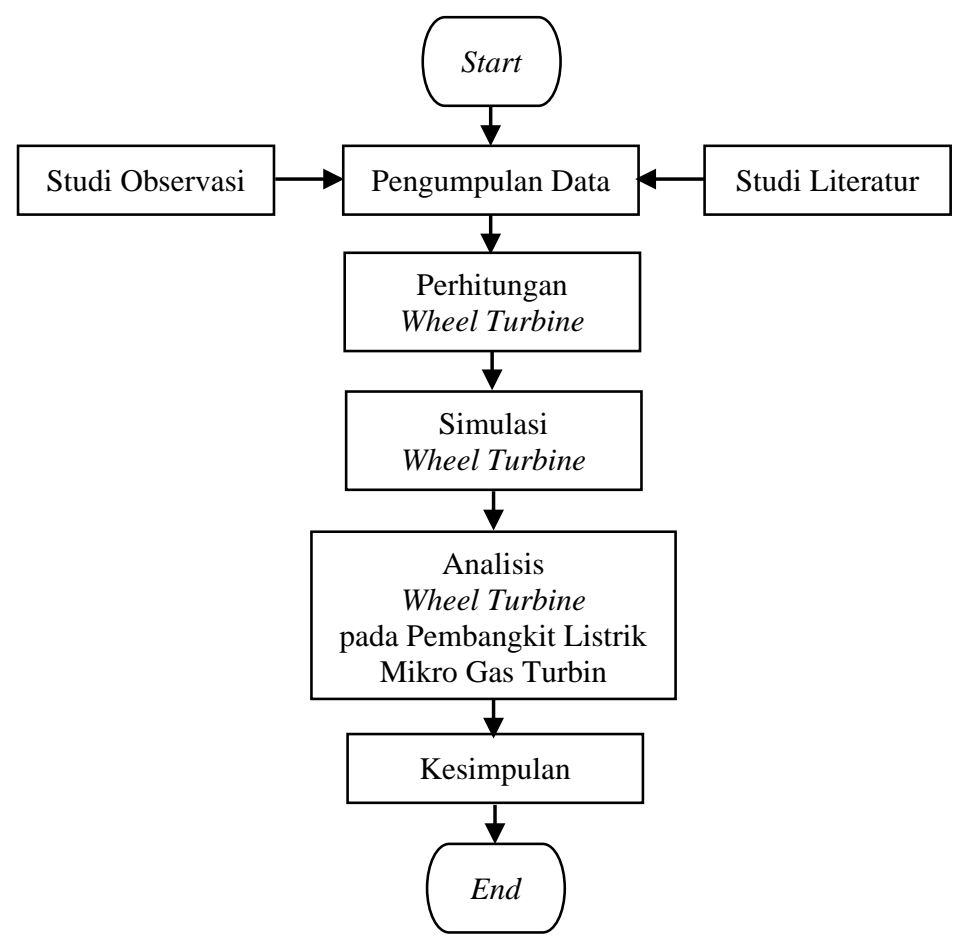

Gambar 3. Diagram alir perancangan wheel turbine pada pembangkit listrik mikro gas turbin.

\section{PERHITUNGAN TERMODINAMIKA}

\section{Siklus Brayton Ideal}

Siklus ideal pada turbin gas mikro yaitu siklus Brayton, siklus ini mengalami penyimpangan dari keadaan ideal dikarenakan adanya kerugian yang terjadi pada setiap komponen instalasi turbin gas mikro. Untuk menganalisis siklus tersebut, dibutuhkan data-data yang dibutuhkan pada kondisi awal dan kondisi akhir sistem [7,9]. Berdasarkan data-data yang diperoleh, diketahui suhu udara (suhu masuk kompressor) sebesar $27^{\circ} \mathrm{C}$, tekanan atmosfer sebesar 1.01325 bar, dan temperatur masuk turbin sebesar $1200^{\circ} \mathrm{C}$ (berdasarkan pada ketahanan material turbin turbocharge yang digunakan) [10,11].

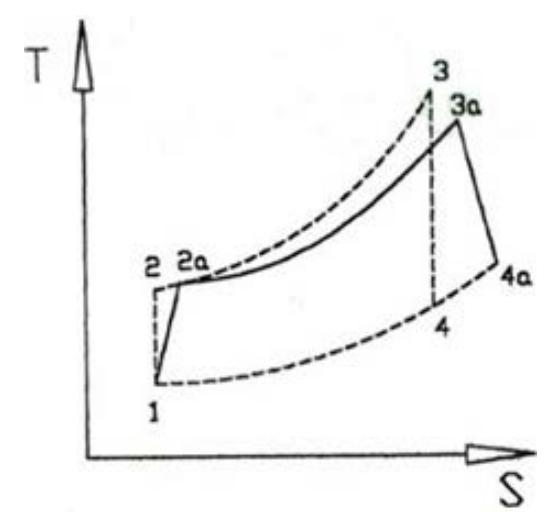

Gambar 4. Diagram T-S siklus Brayton ideal dan aktual [7,9]

Beberapa perhitungan perancangan turbin gas mikro dapat dilakukan berdasarkan perhitungan yang ditunjukkan pada persamaan di Tabel 1 berikut. 
Tabel 1. Persamaan dalam perhitungan rancangan turbin gas mikro dalam kondisi siklus Brayton ideal

\begin{tabular}{cc}
\hline Parameter & Persamaan \\
\hline Rasio tekanan [9] & $r p_{\text {optimum }}=\left(\frac{T_{3}}{T_{1}}\right)^{\frac{k}{2(k-1)}}$
\end{tabular}

$$
r p_{\text {optimum }}=\left(\frac{T_{3}}{T_{1}}\right)^{\frac{k}{2(k-1)}}
$$

Dengan $\mathrm{rp}_{\text {optimum }}=$ rasio tekanan; $\mathrm{T}_{3}=$ suhu gas masuk turbin; $\mathrm{T}_{1}=$ suhu udara masuk kompresor; $\mathrm{k}=$ perbandingan kalor spesifik

Kerja kompresor ideal [9] $\quad W k_{\text {ideal }}=\left(h_{2}-h_{1}\right)$

Dengan $\mathrm{Wk}_{\text {ideal }}=$ kerja kompressor ideal; $\mathrm{h}_{2}=$ enthalpy udara keluar kompressor; $\mathrm{h}_{1}=$ enthalpy udara masuk kompressor

Panas ideal ruang bakar [9] $\quad \operatorname{Qin}_{\text {ideal }}=\left(h_{3}-h_{2}\right)$

Dengan Qin $_{\text {ideal }}=$ panas ideal masuk ruang bakar; $\mathrm{h}_{3}=$ enthalpy gas masuk turbin; $\mathrm{h}_{2}=$ enthalpy udara keluar kompressor

Kerja turbin ideal [9] $W t_{\text {ideal }}=\left(h_{3}-h_{4}\right)$

Dengan $\mathrm{Wt}_{\text {ideal }}=$ kerja turbin ideal; $\mathrm{h}_{3}=$ enthalpy gas masuk turbin; $\mathrm{h}_{4}=$ enthalpy gas keluar turbin

Panas yang keluar [12]

$$
\text { Qout }_{\text {ideal }}=\left(h_{4}-h_{1}\right)
$$

Dengan Qout $_{\text {ideal }}=$ panas ideal keluar ruang bakar; $\mathrm{h}_{4}=$ enthalpy gas keluar turbin; $\mathrm{h}_{1}=$ enthalpy udara masuk kompressor

Efisiensi termal siklus ideal [12]

$$
\eta_{\text {thideal }}=\frac{W t_{\text {ideal }}-W k_{\text {ideal }}}{\text { Qin }_{\text {ideal }}}
$$

Dengan $\eta$ th $_{\text {ideal }}=$ efisiensi termal siklus ideal; $\mathrm{Wt}_{\text {ideal }}=$ kerja turbin ideal; $\mathrm{Wk}_{\text {ideal }}=$ kerja kompressor ideal; Qin $_{\text {ideal }}=$ panas ideal masuk ruang bakar

Back work ratio (bwr) [12]

$$
b w r=\frac{W k_{\text {ideal }}}{W t_{\text {ideal }}}
$$

Dengan bwr = back work ratio; $\mathrm{Wk}_{\text {ideal }}=$ kerja kompressor ideal; $\mathrm{Wt}_{\text {ideal }}=$ kerja turbin ideal

Sehingga 52.14\% kerja ideal turbin digunakan untuk memutar kompresor.

\section{Siklus Brayton Aktual}

Dalam perhitungan siklus Bryton aktual penulis menggunakan beberapa parameter yang telah tersedia oleh spesifikasi turbhocharger yang akan digunakan. Turbocharger yang digunakan adalah GARRETT TA 31 dengan spesifikasi antara lain bilangan Prandtl (Pr) adalah 2.4, ketahanan suhu turbin adalah $1200^{\circ} \mathrm{C}$, dan laju aliran massa sebesar $0.0233-0.18 \mathrm{~m}^{3} / \mathrm{s}$ (Mashuri, 2017). Kondisi udara masuk kompressor diperoleh suhu masuk $\left(\mathrm{T}_{1}\right)$ sebesar $300 \mathrm{~K}$, enthalpy masuk $\left(\mathrm{h}_{1}\right)$ sebesar 300.19 kJ/kg, bilangan Prandtl $\left(\mathrm{Pr}_{1}\right)$ sebesar 1.5374, dan tekanan masuk $\left(\mathrm{P}_{1}\right)$ sebesar 1.02 bar; sedangkan pada kondisi udara keluar kompressor diperoleh suhu keluar $\left(\mathrm{T}_{2}\right)$ sebesar $323.15 \mathrm{~K}$ yang merupakan suhu ketahanan material dari turbocharger Garrett TA 31 dengan perbandingan tekanan sebesar 2.8 bar [13]. Kondisi gas masuk turbin diperoleh suhu masuk $\left(\mathrm{T}_{3}\right)$ sebesar $1473 \mathrm{~K}$ dengan enthalpy gas masuk turbin sebesar $1611.79 \mathrm{~kJ} / \mathrm{kg}$, sedangkan suhu keluar gas turbin $\left(\mathrm{T}_{4}\right)$ sebesar $1097.59 \mathrm{~K}$ dan enthalpy gas keluar turbin sebesar $1161.07 \mathrm{~kJ} / \mathrm{kg}$ [12].

Perbandingan tekanan kompresi sebesar 2.8:1 dengan kenaikan suhu udara yang melewati kompresor, $\mathrm{T}_{2}-\mathrm{T}_{1}=323.15-300=23.15 \mathrm{~K}$, tekanan maksimum kompresor sebesar $\mathrm{P}=2.8$ bar. maka didapat efisiensi isentropik kompresor $\left(\eta_{\mathrm{k}}\right)$ sebesar 85\% [9]. Sedangkan untuk efisiensi turbin $\left(\eta_{\mathrm{T}}\right)$ dapat dicari dengan menggunakan rumus yang ditunjukkan pada Persamaan 8 [12]. 
$\eta_{T}=\frac{\ln \left[1-\eta_{k}+\eta_{k}\left(\frac{P_{2}}{P_{1}}\right)^{\frac{k-1}{k}}\right]}{\left(\frac{k-1}{k}\right) \ln \left(\frac{P_{1}}{P_{2}}\right)}$

Dengan $\eta_{\mathrm{k}}=$ efisiensi isentropik kompresor; $\mathrm{k}=$ perbandingan kalor spesifik; $\mathrm{P}_{1}=$ tekanan udara masuk pada kompressor; $\mathrm{P}_{2}=$ tekanan udara keluar pada kompressor, maka diperoleh sebesar 95,48 \%. Beberapa persamaan dalam perhitungan perancangan turbin gas mikro dalam kondisi siklus Brayton aktual dapat diketahui pada Tabel 2.

Tabel 2. Persamaan dalam perhitungan rancangan turbin gas mikro dalam kondisi siklus Brayton aktual

\begin{tabular}{cc}
\hline Parameter & Persamaan \\
\hline Kerja aktual kompressor [12] & $W k_{\text {aktual }}=\frac{h_{2}-h_{1}}{\eta_{k}}$
\end{tabular}

Dengan $\mathrm{Wk}_{\mathrm{aktual}}=$ kerja kompressor aktual; $\mathrm{h}_{2}=$ enthalpy udara keluar kompressor; $\mathrm{h}_{1}=$ enthalpy udara masuk kompressor; $\eta \mathrm{k}=$ efisiensi isentropik kompresor

Kerja aktual turbin [13] $W t_{\text {aktual }}=\eta_{T} \cdot W t_{\text {ideal }}$

Dengan $\mathrm{Wt}_{\mathrm{aktual}}=$ kerja turbin aktual; $\eta \mathrm{th}=$ efisiensi termal siklus Brayton; $\mathrm{Wt}_{\text {ideal }}=$ kerja turbin ideal

Suhu aktual keluar turbin [13] $\quad h_{4}=h_{3}-W t_{\text {aktual }}$

Dengan $\mathrm{h}_{4}=$ enthalpy gas keluar turbin; $\mathrm{h}_{3}=$ enthalpy gas masuk turbin; $\mathrm{Wt}_{\text {aktual }}=$ kerja turbin aktual

Energi panas aktual yang masuk turbin $\quad Q_{i n}=\left(h_{3}-h_{2}\right)$

[13]

Dengan $\mathrm{Q}_{\text {in }}=$ panas yang masuk ke dalam ruang bakar; $\mathrm{h}_{3}=$ enthalpy gas masuk turbin; $\mathrm{h}_{2}=$ enthalpy udara keluar kompressor

Kerja bersih [13] $\quad W_{\text {net }}=W t_{\text {aktual }}-W k_{\text {aktual }}$

Dengan $\mathrm{W}_{\text {net }}=$ kerja bersih; $\mathrm{Wt}_{\mathrm{aktual}}=$ kerja turbin aktual; $\mathrm{Wk}_{\mathrm{aktual}}=$ kerja kompressor aktual

$$
\text { Back work ratio (bwr) [12] } \quad b w r=\frac{W k_{\text {aktual }}}{W t_{\text {aktual }}}
$$

Dengan bwr = back work ratio; $\mathrm{Wt}_{\mathrm{aktual}}=$ kerja turbin aktual; $\mathrm{Wk}_{\mathrm{aktual}}=$ kerja kompressor aktual

Effisiensi thermal siklus aktual [12]

$$
\eta_{t h}=\frac{W_{\text {net }}}{Q_{\text {in }}}
$$

Dengan $\eta$ th $_{\text {aktual }}=$ efisiensi termal siklus aktual; $\mathrm{W}_{\text {net }}=$ kerja bersih; $\mathrm{Q}_{\text {in }}=$ panas yang masuk ke dalam ruang bakar
FAR $_{\text {aktual }}[12]$

$$
(F A R)_{a k t u a l}=\frac{Q_{i n}}{L H V}
$$

Dengan FAR = Fuel-Air Ratio siklus Brayton aktual; $\mathrm{Q}_{\text {in }}=$ panas yang masuk ke dalam ruang bakar; LHV = lower heat value
AFR $_{\text {aktual }}[12]$

$$
(A F R)_{a k t u a l}=\frac{1}{(F A R)_{a k t u a l}}
$$

Dengan AFR = Air-Fuel Ratio siklus Brayton aktual; FAR = Fuel-Air Ratio siklus Brayton aktual 
Lanjutan Tabel 2. Persamaan dalam perhitungan rancangan turbin gas mikro dalam kondisi siklus Brayton aktual

\begin{tabular}{lc}
\hline \multicolumn{1}{c}{ Parameter } & Persamaan \\
\hline \begin{tabular}{l} 
Laju aliran udara yang disuplai [12] \\
$\begin{array}{l}\text { Dengan } \mathrm{P}_{\mathrm{n} \text { aktual }}=\text { = Daya turbin aktual; } \mathrm{P}_{\mathrm{n}}=\text { daya turbin; } \eta_{\text {th }}=\text { effisiensi thermal; } \eta_{\text {gas }}=\text { efisiensi } \\
\text { thermal gas }\end{array}$ \\
\hline Torsi yang dihasilkan oleh turbin [12] \\
Dengan $\tau$ = torsi; P daya; $\mathrm{n}=$ kecepatan putar mesin
\end{tabular} \\
\hline
\end{tabular}

Untuk memenuhi kebutuhan accu yang akan diteruskan oleh inverter, altenator yang dibutuhkan adalah berkapasitas 100 ah, altenator yang digunakan tetap sama pada penelitian sebelumnya dengan spesifikasi antara lain arus sebesar $100 \mathrm{~A}$, tegangan kerja sebesar 12-14 Volt, torsi sebesar $30 \mathrm{Nm}$, da putaran yang dibutuhkan sebesar $3000 \mathrm{rpm}$. Untuk memutar alternator diperlukan daya yang dapat dihitung dengan persamaan 20 [12].

$$
P=\frac{\tau 2 \pi n}{60}
$$

Dengan $\mathrm{P}=$ daya alternator; $\tau=$ torsi; $\mathrm{n}=$ kecepatan putar turbin

\section{PERBANDINGAN TERMODINAMIKA}

Dengan menghitung kembali termodinamika dengan menggunakan turbin dari garrett ta 31 menghasilkan data yang ditunjukkan pada Tabel 3.

Tabel 3. Perbandingan hasil siklus Brayton ideal dan aktual pada rancangan awal dan modifikasi rancangan turbin gas mikro

\begin{tabular}{|c|c|c|c|}
\hline No. & $\begin{array}{c}\text { Siklus Brayton Ideal } \\
\text { Parameter }\end{array}$ & Nilai Lama & Nilai Baru \\
\hline 1. & $\mathrm{rP}_{\text {optimum }}$ & 11,10 & 16,20 \\
\hline 2. & $\mathrm{Wk}_{\text {ideal }}$ & $8,54 \mathrm{~kJ} / \mathrm{kg}$ & $23,08 \mathrm{~kJ} / \mathrm{kg}$ \\
\hline 3. & Qin $_{\text {ideal }}$ & $987,07 \mathrm{~kJ} / \mathrm{kg}$ & $1288,52 \mathrm{~kJ} / \mathrm{kg}$ \\
\hline 4. & $\mathrm{Wt}_{\text {ideal }}$ & $633,95 \mathrm{~kJ} / \mathrm{kg}$ & $789,84 \mathrm{~kJ} / \mathrm{kg}$ \\
\hline 5. & Qout $_{\text {ideal }}$ & $361,66 \mathrm{~kJ} / \mathrm{kg}$ & $521,76 \mathrm{~kJ} / \mathrm{kg}$ \\
\hline 6. & $\eta$ th $_{\text {siklus }}$ & $49,5 \%$ & $59,5 \%$ \\
\hline 7. & bwr & $1,4 \%$ & $2,9 \%$ \\
\hline \multirow[t]{2}{*}{ No. } & Siklus Brayton Aktual & \multirow{2}{*}{ Nilai Lama } & \multirow{2}{*}{ Nilai Baru } \\
\hline & Parameter & & \\
\hline 1. & $\begin{array}{l}\text { Kondisi udara masuk kompressor } \\
\mathrm{T}_{1}\end{array}$ & $309 \mathrm{~K}$ & $300 \mathrm{~K}$ \\
\hline & $\mathrm{h}_{1}$ & $309,23 \mathrm{~kJ} / \mathrm{kg}$ & $300,19 \mathrm{~kJ} / \mathrm{kg}$ \\
\hline \multirow{3}{*}{2.} & Kondisi udara keluar kompressor & & \\
\hline & $\mathrm{T}_{2}$ & $318 \mathrm{~K}$ & $323,15 \mathrm{~K}$ \\
\hline & $\mathrm{h}_{2}$ & $318,28 \mathrm{~kJ} / \mathrm{kg}$ & $323,17 \mathrm{~kJ} / \mathrm{kg}$ \\
\hline \multirow[t]{3}{*}{3.} & Kondisi gas masuk turbin & & \\
\hline & $\mathrm{T}_{3}$ & $1223 \mathrm{~K}$ & $1473 \mathrm{~K}$ \\
\hline & $\mathrm{h}_{3}$ & $1304,85 \mathrm{~kJ} / \mathrm{kg}$ & $1611,79 \mathrm{~kJ} / \mathrm{kg}$ \\
\hline \multirow[t]{3}{*}{4.} & Kondisi gas keluar turbin & & \\
\hline & $\mathrm{T}_{4}$ & $911.04 \mathrm{~K}$ & $1097.59 \mathrm{~K}$ \\
\hline & $\mathrm{h}_{4}$ & $945,27 \mathrm{~kJ} / \mathrm{kg}$ & $1161,07 \mathrm{~kJ} / \mathrm{kg}$ \\
\hline 5. & Wkaktusl & $9,2 \mathrm{~kJ} / \mathrm{kg}$ & $24,29 \mathrm{~kJ} / \mathrm{kg}$ \\
\hline 6. & Wtaktual & $352,02 \mathrm{~kJ} / \mathrm{kg}$ & $428,18 \mathrm{~kJ} / \mathrm{kg}$ \\
\hline 7. & Qinaktual & $986,23 \mathrm{~kJ} / \mathrm{kg}$ & $1288,52 \mathrm{~kJ} / \mathrm{kg}$ \\
\hline
\end{tabular}


Lanjutan Tabel 3. Perbandingan hasil siklus Brayton ideal dan aktual pada rancangan awal dan modifikasi rancangan turbin gas mikro

\begin{tabular}{|c|c|c|c|}
\hline \multirow[t]{2}{*}{ No. } & Siklus Brayton Aktual & \multirow{2}{*}{ Nilai Lama } & \multirow{2}{*}{ Nilai Baru } \\
\hline & Parameter & & \\
\hline 8. & Qout $_{\text {aktual }}$ & $952,83 \mathrm{~kJ} / \mathrm{kg}$ & $1183,60 \mathrm{~kJ} / \mathrm{kg}$ \\
\hline 9. & bwr & $2,6 \%$ & $5,6 \%$ \\
\hline 10. & $\eta$ th $_{\text {siklus aktual }}$ & $34,5 \%$ & $31,34 \%$ \\
\hline 11. & Daya yang dihasilkan & $0,23 \mathrm{~kW}$ & $3,1 \mathrm{~kW}$ \\
\hline 12. & Torsi turbin & & $0,29 \mathrm{Nm}$ \\
\hline 13. & Daya alternator & & $9,42 \mathrm{~kW}$ \\
\hline
\end{tabular}

\section{SIMULASI CFD}

Hasil dari optimalisasi wheel turbine pada pembangkit listrik mikro gas turbin selanjutnya dilakukan analisis dengan menggunakan simulasi solidworks yang meliputi beberapa parameter yaitu, suhu pada wheel turbine, tekanan yang terjadi dan kecepatan fluida. Analisis hasil distribusi tekanan pada wheel turbine didapat pada tekanan 2,23 bar - 4,34 bar.

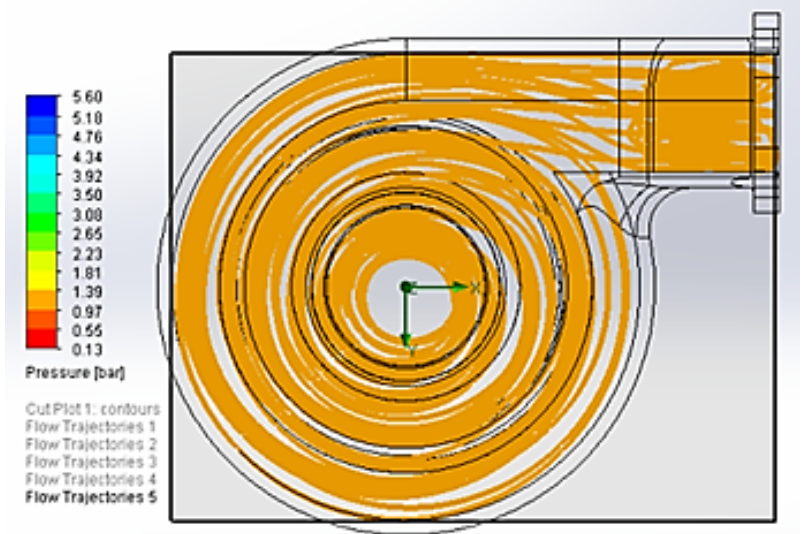

Gambar 6. Hasil distribusi tekanan statis

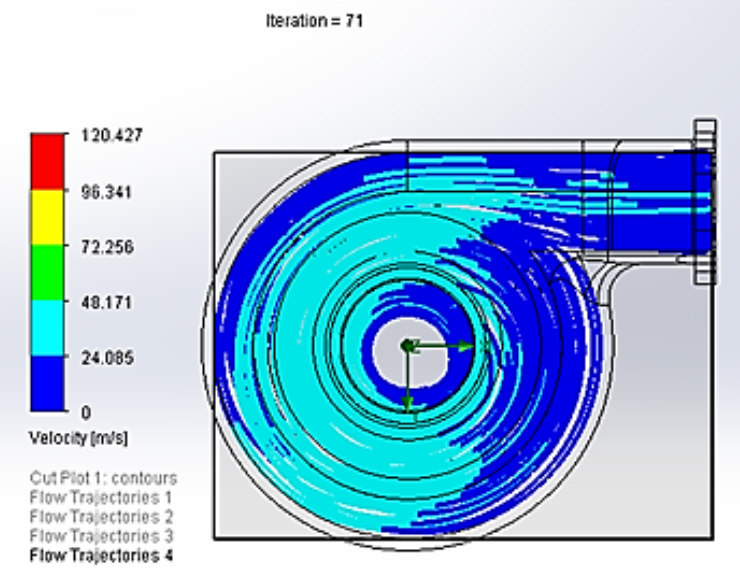

Gambar 7. Hasil distribusi kecepatan fluida
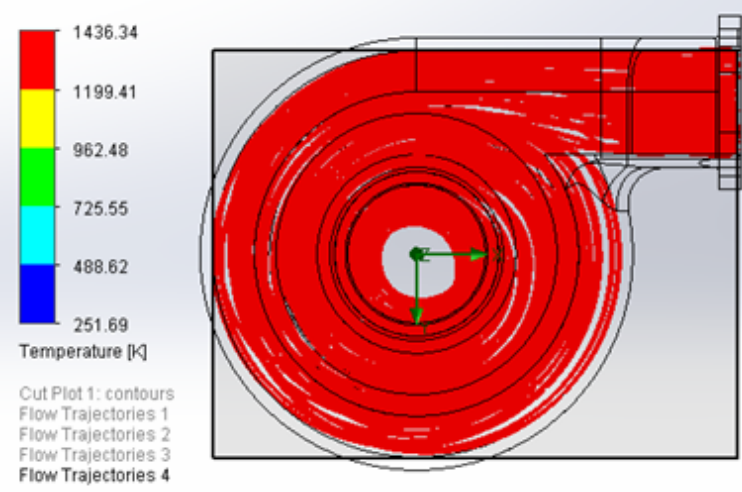

Gambar 8. Hasil distribusi kecepatan fluida

Berikutnya yaitu hasil analisis distribusi kecepatan yang terjadi pada wheel turbine garrett ta 31. Dengan memasukkan parameter yang telah dihitung melalui perhitungan termodinamika, dapat ditemukan dengan hasil distribusi kecepatan fluida sebesar 24.05 m/s.

Analisis distribusi temperatur statis merupakan distibusi suhu yang terdapat pada wheel turbine garrett ta 31. Pada wheel turbine garrett ta 31 terdapat temperatur merata pada inlet wheel turbine yaitu $1436.34 \mathrm{~K}$. 


\section{SIMPULAN}

Dari hasil perhitungan mikro gas turbin ini, maka dapat dibuat kesimpulan sebagai berikut:

1. Hasil desain ulang dengan mengganti turbocharger CT 16 diganti dengan turbocharger Garrett TA 31 yang memilki dimensi yang lebih besar dengan tujuan meningkatkan kerja turbin sehingga dapat putaran yang dapat memutar alternator hingga menghasilkan daya listrik yang diinginkan yaitu lebih dari $3000 \mathrm{rpm}$.

2. Hasil analisis wheel turbine menggunkan turbin turbocharger Garrett TA 31:

a. Tekanan pada volute Garret TA 31 merata yaitu dengan tekanan 2.23 - 4.34 bar

b. Distribusi kecepatan pada wheel turbin yaitu $20.05 \mathrm{~m} / \mathrm{s}$

c. Pada temperature yang terjadi pada wheel turbin yaitu $1436.34 \mathrm{~K}$

3. Analisis efisiensi termal siklus meningkat dengan menggunakan Garret TA 31 menjadi 59.5\%

4. Daya output yang dihasilkan: menjadi $3.1 \mathrm{Kw}$

\section{SARAN} berikut:

Dari hasil perhitungan termodinamika mikro gas turbin ini, maka dapat dibuat saran sebagai

1. Perlunya pencarian alternatif jenis turbin yang menghasilkan putaran tinggi, sehingga menghasilkan pembangkit listrik yang baik

2. Diperlukan pengujian kualitas dari turbocharge yang digunakan. Karena turbocharge sangat berpengaruh dalam efisiensi siklus MGT. Terutama pada kemungkinan gaya kinetik poros.

\section{DAFTAR PUSTAKA}

[1] Marsudi, D. (2011). Pembangkitan Energi Listrik, Kedua. Erlangga, Jakarta.

[2] Pudjanarsa, A. Djati, N. (2013). Mesin Konversi Energi, Ketiga. Andi, Yogyakarta.

[3] Yudisworo, W.D. (2017).Studi Alternatif Penggunaan BBG Gas Elpiji Untuk Bahan Bakar Mesin Bensin Konvensional. Skripsi. Universitas 17 Agustus 1945, Jakarta.

[4] Anger, P.L. (2016). Analisa Aliran Fluida Pembangkit Listrik Turbin Gas Mikro dengan Bahan Bakar LPG Menggunakan Computational Fluid Dynamycs (CFD) . Skripsi. Universitas Pancasila, Jakarta.

[5] Riansyah, S. (2014). Perancangan Mikro Gas Turbin Berbahan Bakar Biogas.Skripsi. Universitas Muhammadiyah, Jakarta.

[6] Artanto, A. (2017). Analisa Ruang Bakar Pada Pembangkit Listrik Mikro Turbin Gas Kapasitas 3 kW. Skripsi. Universitas Pancasila, Jakarta.

[7] Tickoo, S. (2017).Solidwork as 2017 for designers. Solidwork Press, United States of America.

[8] Naufal, A. (2017). Rancang Bangun Ruang Bakar Pada Micro Gas Generator Sets. Skripsi. Universitas Pancasila, Jakarta.

[9] Prasetyo, E. Hermawan, D. Zariatun, D.L. (2017). "Fluid Flow Analysis of Micro Gas Turbine Using Computational Fluid Dynamic (CFD)”. Jurnal JOJAPS, 20-22.

[10] Budi, Y. (2017). Analisa Turbin Pada Pembangkit Listrik Microturbin Gas Kapasitas 3 kW. Skripsi. Universitas Pancasila, Jakarta.

[11] Rachmatuloh, A.A. (2017). Perakitan Dan Pengujian Gas Generator Sets. Skripsi. Universitas Pancasila, Jakarta.

[12] Hermawan, R. Prasetyo, E and Pane, E.A. (2017). “Analisa Perancangan ruang Bakar Pada Pembangkit Listrik Mikro Turbin Gas Bahan Bakar LPG”. Seminar Nasional Sains dan Teknologi UMJ, Fakultas Teknik Universitas Muhammadiyah Jakarta, 1-2 November 2017, 1-7.

[13] Mashuri. (2017). Analisa Termodinamika Pembangkit Listrik Mikro Turbin Gas Kapasitas 3 kW. Skripsi. Universitas Pancasila, Jakarta. 